\title{
Efek Suplementasi Vitamin A, Minyak Fortifikasi dan Edukasi Gizi Ibu Nifas terhadap Morbiditas Ibu dan Bayi
}

\author{
Effect of Vitamin A Supplementation, Oil Fortification and Nutrition \\ Education to Postpartum Mother on Morbidity of Mother and Infant
}

\author{
Abdul Salam ${ }^{1,2 *}$, Dodik Briawan', Drajat Martianto', Abdul Razak Thaha ${ }^{2}$, \\ Andi Imam Arundhana ${ }^{2}$ \\ ${ }^{1}$ Departemen Gizi Masyarakat, Fakultas Ekologi Manusia, Institut Pertanian Bogor \\ ${ }^{2}$ Departemen Gizi, Fakultas Kesehatan Masyarakat, Universitas Hasanuddin, Makassar \\ (*salamgiziuh@gmail.com)
}

\begin{abstract}
ABSTRAK
Kekurangan vitamin A dapat berpengaruh pada peningkatan morbiditas ibu nifas maupun bayi yang baru lahir. Tujuan penelitian ini adalah untuk mengetahui dampak pemberian vitamin A dosis tinggi (2vitA dan 1vitA), minyak goreng fortifikasi (Forti A) dan edukasi gizi (Edukasi) terhadap morbiditas ibu dan bayi. Penelitian ini menggunakan desain kuasi ekpesimen. Jumlah subjek dalam penelitian ini sebesar 295 subjek yang dipilih berdasarkan kriteria inklusi. Morbiditas terutama terkait ISPA dan diare diukur setiap 2 minggu sampai bayi berusia 3 bulan. Hasil penelitian menunjukkan rata-rata ibu nifas dalam penelitian ini berusia 27 tahun dan sekitar $42 \%$ ibu nifas telah menyelesaikan pendidikan sampai tingkat SMA. Rata-rata frekuensi sakit ISPA ibu pada kelompok Forti A lebih rendah dibandingkan dengan kelompok 2vitA, 1vitA dan edukasi yakni masing-masing 0.04, 0.31, 0.95 dan $0.29(\mathrm{p}<0.000)$. Begitu pun juga halnya ditemukan pada durasi ISPA untuk setiap kelompok yakni masing-masing 0,17 hari,0.99 hari, 3.16 hari, dan 1.07 hari $(\mathrm{p}<0.000)$. Pemberian minyak fortifikasi dapat mengurangi kejadian morbiditas.
\end{abstract}

Kata kunci : Suplementasi vitamin A, minyak fortifikasi, edukasi, ibu nifas, morbiditas

\section{ABSTRACT}

Vitamin A deficiency can affect the morbidity of postpartum mother and their infant. The purpose of this study was to determine the effect of high doses of vitamin A (2vitA and 1vitA), fortified oil (Forti A) and nutrition education (Education) on maternal and infant morbidity. This study was used quasi experimental design with total 295 samples selected based on the inclusion criteria. Morbidity which mainly associated with ARI and diarrhea was measured every two weeks until the infant is 3 months old. The results showed that the average postpartum mothers in this study were 27 years old and about $42 \%$ of postpartum mothers had completed their education up to high school level. The average frequency of maternal ARI in the Forti A group was lower compared to the 2vitA, 1 vitA and educational groups $(0.04,0.31,0.95$, and 0.29 , respectively) $(p<0.000)$. Likewise, it is also found in the duration of respiratory infection for each group of; $0.17,0.99,3.16$, and 1.07 day, respectively $(p<0.000)$. Oil fortification with vitamin A can reduce the incidence of morbidity.

Keywords : Vitamin A supplementation, oil fortification, education, postpartum mother, morbidity

Copyright (C) 2018 Universitas Hasanuddin. This is an open access article under the CC BY-NC-SA license

(https://creativecommons.org/licenses/by-nc-sa/4.0/).

DOI : http://dx.doi.org/10.30597/mkmi.v14i3.4348 


\section{PENDAHULUAN}

Kejadian kekurangan vitamin A berhubungan erat dengan peningkatan kejadian morbiditas diare dan kematian pada anak-anak. Selain itu, status vitamin A dalam tubuh dapat dipengaruhi oleh tingginya insiden penyakit seperti diare, disentri, campak dan infeksi saluran pernapasan akut. ${ }^{1,2} \mathrm{Vi}$ tamin A memainkan peran penting dalam penglihatan, pertumbuhan dan perkembangan fisik, dan fungsi imunitas. ${ }^{3}$ Kekurangan vitamin A meningkatkan risiko buta senja dan gangguan penglihatan yang lain seperti xeropthalmia. Selain itu, vitamin A juga berfungsi untuk memelihara kesehatan ibu selama hamil dan menyusui. ${ }^{4,5}$ Di negara berkembang kekurangan vitamin A pada anak-anak dapat disebabkan karena beberapa faktor. Diantara penyebab tersebut seperti ibu menyusui mengalami kekurangan asupan vitamin A yang mengakibatkan konsentrasi vitamin A dalam air susu ibu (ASI) rendah, asupan makanan sumber vitamin A tidak memadai selama dan setelah anak disapih, serta adanya penyakit infeksi yang berulang. ${ }^{6,7}$

Status vitamin A pada kebanyakan bayi baru lahir termasuk dalam kategori ambang batas bawah, ${ }^{8-11}$ dan ketika ibu menyusui memiliki asupan vitamin A yang tidak cukup maka peluang bayi mengalami kekurangan vitamin A semakin besar. Perlindungan bayi dari kekurangan vitamin A bisa diatasi dengan memberikan ASI dengan syarat konsentrasi vitamin A dalam ASI juga memadai. Untuk meningkatkan konsentrasi vitamin A dalam ASI, maka suplementasi vitamin A terhadap ibu menyusui telah diusulkan sebagai strategi alternatif untuk meningkatkan asupan vitamin A bayi yang disusui secara ekslusif sampai usia 6 bulan. ${ }^{12}$

Tahun 2011 World Health Organization (WHO) telah mengeluarkan pedoman terbaru terkait suplementasi vitamin A pada ibu nifas. Dalam pedoman tersebut, WHO merekomendasikan bahwa suplementasi vitamin A dosis tinggi kepada ibu nifas sesaat setelah melahirkan tidak lagi diperlukan. Beberapa hasil penelitian menunjukkan suplementasi vitamin A ibu nifas tidak memberikan efek yang signifikan pada morbiditas dan mortalitas ibu maupun bayi usia $0-6$ bulan. ${ }^{13}$ Selain itu, WHO juga mengharapkan dimasa mendatang perlu ada penelitian yang melihat efek suplementasi vitamin A tepat pada 6 minggu setelah ibu mela- hirkan sebagai alternatif lain selain suplementasi sesaat setelah melahirkan. Rekomendasi ini muncul kemungkinan disebabkan karena pada dasarnya kadar vitamin A dalam ASI masih tinggi dalam 21 hari pertama setelah ibu melahirkan. ${ }^{13}$ Sehingga jika tetap diberikan suplementasi vitamin A sesaat setelah melahirkan, maka kemungkinan tidak akan memberikan efek yang signifikan.

Dalam rekomendasi terbaru WHO terkait suplementasi vitamin A pada ibu nifas, dianjurkan agar ibu harus terus didorong untuk memperoleh asupan gizi yang cukup. Konsumsi buah dan sayur terutama yang mengandung vitamin A juga dapat menjadi salah satu alternatif untuk memenuhi kebutuhan vitamin A ibu nifas. Namun, hasil Riset Kesehatan Dasar tahun 2013 menunjukkan bahwa sekitar $93.5 \%$ penduduk usia $\geq 10$ tahun yang masih kurang mengonsumsi sayur dan buah. ${ }^{14}$ Terkait hal tersebut, perlu adanya upaya komunikasi, informasi, dan edukasi untuk meningkatkan konsumsi makanan sumber vitamin A yang berasal dari buah dan sayur terutama pada saat hamil dan juga saat ibu menyusui.

Selain dengan suplementasi maupun edukasi, cara lain yang bisa ditempuh yang bisa dilakukan untuk mengatasi masalah kekurangan vitamin A pada ibu menyusui adalah dengan melakukan fortifikasi pangan. ${ }^{15}$ Penelitian oleh Sandjaja et.al menunjukkan bahwa pemberian minyak goreng yang difortifikasi vitamin A dapat menaikkan kadar vitamin dalam ASI ibu menyusui usia 6-12 bulan. ${ }^{16}$ Namun, penelitian tersebut belum melihat efek intervensi terhadap tingkat kejadian morbiditas baik ibu maupun anak. Tujuan penelitian ini adalah untuk mengetahui pengaruh pemberian suplementasi vitamin A dosis tinggi, minyak goreng fortifikasi maupun edukasi gizi pada ibu nifas terhadap tingkat kejadian morbiditas ibu maupun bayi di 3 bulan pertama kehidupan.

\section{BAHAN DAN METODE}

Penelitian menggunakan metode kuasi eksperimen. Terdapat empat kelompok intervensi dalam penelitian ini yakni (1) kelompok yang mendapatkan 2 kapsul vitamin A dosis 200.000 SI sesaat setelah melahirkan (2VitA); (2) kelompok yang mendapatkan 1 kapsul vitamin A dosis 200.000 SI minggu ke 6 setelah melahirkan (1VitA), dosis pemberian kapsul vitamin A ini 
berdasarkan rekomendasi terbaru WHO tahun 2011 ; (3) kelompok yang mendapatkan minyak goreng yang difortifikasi dengan vitamin A (Forti A); dan (4) kelompok ibu nifas yang mendapatkan edukasi terkait gizi (edukasi). Penelitian ini dilaksanakan di 7 (tujuh) Puskesmas di Kabupaten Gowa dari bulan Juli 2017 sampai Maret 2018 dan telah mendapatkan persetujuan etik dari Komisi Etik Penelitian yang Melibatkan Subjek Manuasia (KEPMSM) Institut Pertanian Bogor (No. 01/IT3. KEPMSM-IPB/SK/2017).

Subjek penelitian ini adalah ibu hamil yang sudah memasuki usia kehamilan trimester ke-3 di wilayah kerja puskesmas Kabupaten Gowa dengan kriteria, 1) melahirkan secara normal dan cukup bulan, 2) memiliki bayi dengan berat lahir masuk kategori normal, dan 3) maksimal paritas ke-3. Alasan pemilihan kriteria ini adalah karena beberapa penelitian melaporkan bahwa bayi prematur ataupun memiliki berat badan rendah dan lahir kurang dari 36 minggu kehamilan memiliki plasma retinol dan Retinol Binding Protein (RBP) yang rendah dibandingkan dengan bayi yang lahir cukup bulan. ${ }^{17}$ Selanjutnya terkait paritas, hasil penelitian menunjukkan bahwa ibu primipara memiliki konsetrasi lipid dalam ASI yang lebih tinggi daripada ibu multipara. Konsentrasi lipid yang tinggi tersebut akan berpengaruh pada tingginya kadar retinol di dalam ASI. ${ }^{18}$

Jumlah minimal subjek yang dibutuhkan untuk penelitian ini dihitung menggunakan rumus uji hipotesis beda proporsi yaitu 61 orang di tiap perlakuan. Pada tahap skrining sebanyak $314 \mathrm{ibu}$ hamil (calon responden) di wawancara dan diminta kesediaannya untuk ikut dalam penelitian. Namun, hanya 297 yang memenuhi kriteria inklusi dan bersedia ikut terlibat dalam penelitian dengan rincian 73 orang pada kelompok 2VitA, 74 orang pada kelompok 1vitA, 77 orang pada kelompok Forti A, dan 73 orang pada kelompok edukasi. Hingga akhir penelitian dua subjek dinyatakan drop out, masing-masing satu orang di kelompok 2VitA dan kelompok Forti A dikarenakan pindah dari lokasi penelitian ke kabupaten lain.

Pemberian kapsul vitamin A untuk kelompok 2vitA yakni 1 kapsul sesaat setelah melahirkan dan 1 kapsul minimal 24 jam setelah pemberian kapsul pertama. Selanjutnya untuk kelompok 1vitA kapsul diberikan pada saat minggu ke 6 setelah ibu melahirkan dengan melakukan kunjungan ke rumah ibu nifas. Untuk kelompok Forti A, minyak goreng yang digunakan adalah minyak goreng pabrikan bermerek yang telah difortifikasi dengan 45 SI vitamin A retinil palmitat. Proses fortifikasi minyak goreng tidak dilakukan langsung oleh peneliti (dilakukan oleh pihak produsen minyak goreng). Akan tetapi untuk memastikan jumlah kandungan vitamin A dalam minyak, peneliti telah memeriksa kembali kadar vitamin A dalam beberapa minyak goreng yang digunakan untuk penelitian dengan menggunakan alat icheck chro$m a$. Minyak goreng ini didistribusikan ke rumah ibu nifas setiap minggu sebanyak 1 liter selama 3 bulan (total 12 kali pemberian minyak).

Selanjutnya untuk kelompok edukasi, pemberian edukasi gizi dilakukan sebanyak 5 kali yang dibagi dalam dua tahap yakni 2 kali pada saat ibu hamil dan 3 kali pada saat ibu melahirkan (khususnya pada masa nifas). Edukasi pada saat ibu hamil dilakukan dalam bentuk edukasi pada kelompok ibu hamil (maksimal 10 ibu hamil) menggunakan leaflet dan buku saku yang telah disusun oleh tim peneliti dengan durasi sekitar $30-60$ menit. Selanjutnya untuk edukasi saat nifas, dilakukan dengan melakukan kunjungan rumah sebanyak 3 kali, kunjungan pertama dilakukan pada hari ketiga setelah ibu melahirkan (bersamaan dengan wawancara dan pengukuran antropometri ibu nifas), kunjungan kedua dilakukan pada saat minggu ke 2-4 dan kunjungan ketiga diberikan saat minggu ke 5-6 setelah melahirkan. Edukasi saat masa nifas menggunakan buku saku dan leaflet yang sama saat edukasi sewaktu ibu hamil. Durasi edukasi disetiap sesi kunjungan dilakukan sekitar 10-15 menit.

Beberapa informasi yang dikumpulkan dalam penelitian ini seperti informasi terkait karakteristik responden, keadaan sosial ekonomi, riwayat kehamilan dan kelahiran serta bayi yang dilahirkan. Informasi terkait keadaan sosial ekonomi responden maupun bayi yang dilahirkan diperoleh melalui wawancara menggunakanan formulir kuesioner. Ukuran antropometri yakni berat badan dan panjang badan saat bayi lahir, diperoleh dari catatan di buku KIA (Kesehatan Ibu dan Anak) atau dari catatan di pelayanan kesehatan tempat ibu melahirkan.

Informasi mengenai penyakit infeksi ter- 
Tabel 1. Karakteristik Responden Berdasarkan Kelompok Intervensi

\begin{tabular}{|c|c|c|c|c|c|c|}
\hline \multirow[b]{2}{*}{ Karakteristik } & \multicolumn{4}{|c|}{ Kelompok Intervensi } & \multirow[b]{2}{*}{ Total } & \multirow[b]{2}{*}{$\mathbf{p}$} \\
\hline & $\begin{array}{l}\text { 2vitA } \\
n=72\end{array}$ & $\begin{array}{l}\text { 1vitA } \\
\mathrm{n}=74\end{array}$ & $\begin{array}{c}\text { Forti A } \\
n=76\end{array}$ & $\begin{array}{c}\text { Edukasi } \\
n=73\end{array}$ & & \\
\hline \multicolumn{7}{|l|}{ Karakteristik Ibu } \\
\hline Umur ibu (20-25 tahun), \% & 44.4 & 43.2 & 35.5 & 43.8 & 41.7 & 0.72 \\
\hline Umur ayah, tahun (20-30 tahun), \% & 55.6 & 59.5 & 50.0 & 45.8 & 52.7 & 0.27 \\
\hline Pendidikan ibu (tamat SMA), \% & 40.3 & 48.6 & 39.5 & 39.7 & 42.0 & 0.45 \\
\hline Pendidikan ayah (tamat SMA), \% & 43.1 & 45.9 & 53.9 & 35.6 & 44.7 & 0.004 \\
\hline Pekerjaan ibu (IRT), \% & 95.8 & 91.9 & 93.4 & 95.9 & 94.2 & 0.058 \\
\hline Pekerjaan ayah (buruh harian), $\%$ & 40.3 & 36.5 & 26.3 & 28.8 & 32.9 & 0.279 \\
\hline \multicolumn{7}{|l|}{ Karakteristik Anak } \\
\hline Jenis kelamin (perempuan), \% & 55.6 & 47.3 & 39.5 & 46.6 & 47.1 & 0.148 \\
\hline Anak ke (ke 3), \% & 37.5 & 32.4 & 30.3 & 31.5 & 32.9 & 0.701 \\
\hline Dibantu nakes saat melahirkan (Ya), \% & 100 & 100 & 97.4 & 97.2 & 98.6 & 0.145 \\
\hline Berat badan lahir $(2500-3000 \mathrm{~g}), \%$ & 58.3 & 43.2 & 22.4 & 39.7 & 40.7 & 0.000 \\
\hline Tempat melahirkan (Yankes), $\%$ & 100 & 100 & 97.4 & 95.8 & 98.3 & 0.145 \\
\hline
\end{tabular}

Sumber : Data Primer, 2018

utama terkait Infeksi Saluran Pernafasan Akut (ISPA) dan diare baik pada ibu nifas maupun bayinya diperoleh dengan melakukan wawancara menggunakan kuesioner terstruktur yang berisi informasi tentang frekuensi dan durasi penyakit infeksi. Frekuensi yang dimaksud dalam penelitian ini adalah berapa kali ibu maupun bayi menderita sakit sedangkan durasi adalah berapa hari ibu maupun bayi menderita penyakit infeksi dalam kurun waktu 2 minggu terakhir. Frekuensi dan lama menderita penyakit infeksi diukur setiap 2 minggu sampai bayi berusia 3 bulan. Indikator ibu atau anak mengalami diare apabila frekuensi buang air besar lebih dari biasanya ( $>3 \mathrm{kali} / \mathrm{hari})$ disertai perubahan konsistensi tinja (menjadi cair), dengan /tanpa darah atau lendir. Disebut sebagai ISPA apabila memiliki salah satu atau lebih gejala, seperti tenggorokan sakit atau nyeri saat menelan, pilek, batuk kering atau berdahak.

Data yang diperoleh diolah menggunakan program Microsoft Excel dan SPSS for windows. Sebelum analisis lebih lanjut, terlebih dahulu dilakukan uji normalitas untuk memastikan data yang telah dikumpulkan terdistribusi normal atau tidak. Data karakteristik subjek dianalisis menggunakan uji Kruskall Wallis. Data morbiditas ibu maupun anak dianalisis menggunakan Analysis of variance (Anova) untuk mengetahui pengaruh perlakukan terhadap parameter yang diamati. Dikatakan signifikan jika nilai $\mathrm{p}<0.05$.

\section{HASIL}

Tabel 1 menunjukkan karakteristik responden berdasarkan kelompok intervensi. Proporsi subjek berumur 20-25 tahun lebih banyak (41.7\%) dibandingkan dengan kelompok umur lain. Sedangkan kelompok umur untuk suami lebih banyak pada rentang 20 - 30 tahun (52.7\%). Hasil uji statistik menunjukkan tidak ada perbedaan yang signifikan antar setiap kelompok intervensi dalam hal proporsi kelompok usia $(\mathrm{p}>0.05)$. Dari segi tingkat pendidikan, ibu nifas yang menyelesaikan pendidikan sampai tingkat SMA sebesar $42 \%$ sedangkan untuk pendidikan suami sampai tingkat SMA rata-rata $44.7 \%$. Hampir semua ibu nifas dalam penelitian ini bekerja sebagai ibu rumah tangga yakni sekitar $94.2 \%$, sedangkan untuk pekerjaan ayah sekitar $32.9 \%$ yang berprofesi sebagai buruh harian dan paling banyak dijumpai pada kelompok 2VitA (40.3\%). Anak yang dilahirkan berjenis kelamin perempuan sebesar $47.1 \%$, seki$\operatorname{tar} 32.9 \%$ diantaranya merupakan anak ke 3 yang hampir semuanya dilahirkan di tempat pelayanan kesehatan (98.3\%). Sekitar 98.6\% ibu nifas dibantu oleh tenaga kesehatan pada saat melahirkan. Proporsi berat badan lahir bayi lebih banyak pada rentang $2500-3000 \mathrm{~g}(40.7 \%)$.

Tabel 2 menunjukkan frekuensi dan durasi kumulatif kejadian penyakit infeksi baik pada ibu maupun pada bayi sejak dilahirkan sampai berusia 3 bulan. Secara kumulatif, frekuensi maupun 
Tabel 2. Frekuensi dan Durasi Kumulatif Morbiditas Ibu dan Anak antar Kelompok Intervensi

\begin{tabular}{ccccc}
\hline & \multicolumn{3}{c}{ Jumlah Kumulatif Frekuensi (Kumulatif Durasi Sakit dalam Hari) } \\
\cline { 2 - 5 } & \multicolumn{3}{c}{ Ibu } & \multicolumn{3}{c}{ Anak } \\
\cline { 2 - 5 } & ISPA & Diare & ISPA & Diare \\
n(\%) & $\mathbf{n}(\%)$ & $\mathbf{n}(\%)$ \\
\hline Bulan ke-1 & & & & \\
2VitA & $12(13)$ & $7(19)$ & $8(23)$ & $11(29)$ \\
1VitA & $22(79)$ & $2(5)$ & $23(76)$ & $6(9)$ \\
Forti A & 0 & 0 & $4(6)$ & 0 \\
Edukasi & $13(44)$ & $1(1)$ & $8(23)$ & 0 \\
Bulan ke-2 & & & & \\
2VitA & $15(19)$ & $13(29)$ & $15(44)$ & $12(31)$ \\
1VitA & $47(156)$ & $3(7)$ & $59(176)$ & $8(13)$ \\
Forti A & $2(6)$ & 0 & $6(10)$ & 0 \\
Edukasi & $16(49)$ & $1(1)$ & $8(23)$ & $2(3)$ \\
Bulan ke-3 & & & & \\
2VitA & $22(62)$ & $14(30)$ & $26(104)$ & $15(38)$ \\
1VitA & $70(234)$ & $8(14)$ & $118(356)$ & $17(39)$ \\
Forti A & $3(13)$ & $1(1)$ & $19(45)$ & $1(7)$ \\
Edukasi & $21(78)$ & $2(4)$ & $20(54)$ & $6(9)$ \\
\hline
\end{tabular}

Sumber : Data Primer, 2018

Tabel 3. Perbandingan Frekuensi dan Durasi Sakit ISPA dan Diare pada Ibu dan Anak Selama 3 Bulan Observasi

\begin{tabular}{|c|c|c|c|c|c|c|c|c|c|}
\hline \multirow{3}{*}{ Karakteristik } & \multicolumn{8}{|c|}{ Kelompok Intervensi } & \multirow{3}{*}{$\mathbf{p}$} \\
\hline & \multicolumn{2}{|c|}{ 2vitA } & \multicolumn{2}{|c|}{1 vitA } & \multicolumn{2}{|c|}{ Forti A } & \multicolumn{2}{|c|}{ Edukasi } & \\
\hline & Mean & SD & Mean & SD & Mean & SD & Mean & SD & \\
\hline \multicolumn{10}{|l|}{ Morbiditas ibu } \\
\hline Frekuensi ISPA & 0.31 & 0.52 & 0.95 & 0.76 & 0.04 & 0.19 & 0.29 & 0.54 & 0.000 \\
\hline Durasi ISPA & 0.99 & 2.02 & 3.16 & 3.07 & 0.17 & 0.93 & 1.07 & 2.30 & 0.000 \\
\hline Frekuensi diare & 0.19 & 0.62 & 0.11 & 0.31 & 0.01 & 0.11 & 0.03 & 0.16 & 0.011 \\
\hline Durasi diare & 0.42 & 1.54 & 0.19 & 0.59 & 0.01 & 0.11 & 0.05 & 0.37 & 0.010 \\
\hline \multicolumn{10}{|l|}{ Morbiditas anak } \\
\hline Frekuensi ISPA & 0.36 & 0.66 & 1.59 & 0.99 & 0.25 & 0.46 & 0.27 & 0.48 & 0.000 \\
\hline Durasi ISPA & 1.44 & 2.98 & 4.81 & 3.53 & 0.59 & 1.26 & 0.74 & 1.55 & 0.000 \\
\hline Frekuensi diare & 0.21 & 0.50 & 0.23 & 0.48 & 0.01 & 0.11 & 0.08 & 0.32 & 0.001 \\
\hline Durasi diare & 0.53 & 1.39 & 0.53 & 1.27 & 0.09 & 0.80 & 0.12 & 0.49 & 0.001 \\
\hline
\end{tabular}

Sumber : Data Primer, 2018

durasi sakit ISPA pada ibu dan anak paling banyak ditemukan pada kelompok 1vitA (70 kali dan 234 hari), sedangkan untuk frekuensi dan durasi sakit diare pada ibu paling banyak ditemukan pada kelompok 2vitA (14 kali dan 30 hari). Selanjutnya untuk frekuensi dan durasi sakit diare pada anak paling banyak ditemukan pada kelompok 1vitA (17 kali dan 39 hari).

Rata-rata frekuensi kejadian sakit ISPA maupun diare pada ibu lebih rendah ditemukan pada kelompok Forti A dibandingkan dengan kelompok 2vitA, 1vitA dan edukasi (Tabel 3). Be- gitu pula halnya ditemukan pada rata-rata frekuensi sakit ISPA dan diare pada anak, kelompok Forti A lebih rendah dibandingkan 3 kelompok lainnya. Hasil uji statistik menunjukkan ada perbedaan yang signifikan pada rata-rata frekuensi dan durasi sakit ISPA dan diare baik pada ibu maupun anak disetiap kelompok intervensi $(\mathrm{p}<0,05)$.

\section{PEMBAHASAN}

Hasil penelitian menemukan bahwa pemberian minyak goreng fortifikasi lebih baik dalam mengurangi tingkat kejadian (frekuensi) dan juga 
lama (durasi) sakit ISPA dan diare baik pada ibu maupun anak dibandingkan dengan suplementasi vitamin A dan edukasi gizi. Hal ini diketahui dengan melihat pada akhir penelitian, rata-rata frekuensi dan durasi sakit ibu maupun bayi pada kelompok yang diberikan minyak goreng fortifikasi cenderung lebih rendah dibandingkan dengan kelompok intervensi yang lain (meskipun hasil uji Anova memperlihatkan tidak ada perbedaan secara signifikan antara kelompok intervensi, $\mathrm{p}<0.05$ ). Hasil penelitian yang dilakukan oleh Sandjaja et al., menunjukkan bahwa pemberian minyak goreng yang difortifikasi dengan 45 SI retinol/g mampu menaikkan kadar vitamin A ASI ibu dari $20,5 \mu \mathrm{g} / \mathrm{dl}$ saat baseline menjadi 32,5 $\mu \mathrm{g} /$ dl saat endline. ${ }^{16}$ Pada penelitian yang dilakukan oleh Sandjaja et al., tidak melihat sampai pada dampak intervensi tersebut terhadap morbiditas ibu dan anak. Meskipun demikian, hasil tersebut bisa memberikan gambaran bahwa kadar vitamin A dalam ASI dapat meningkat secara signifikan melalui pemberian minyak goreng yang telah difortifikasi dengan vitamin A. Peningkatan tersebut berpotensi meningkatkan imunitas ibu dan bayi sehingga tidak mudah terkena penyakit infeksi. ${ }^{19}$

Dibandingkan dengan kelompok suplementasi vitamin A, rata-rata kejadian sakit ibu maupun anak pada kelompok edukasi gizi masih lebih rendah dibandingkan dengan mereka yang mendapat 2 kapsul vitamin A maupun 1 kapsul vitamin A. Hasil ini berbeda dengan studi yang dilakukan oleh Abdullah et al., yang menemukan bahwa rata-rata frekuensi sakit diare pada kelompok yang mendapat suplementasi lebih rendah dibandingkan kelompok yang mendapatkan penyuluhan. ${ }^{20} \mathrm{Hal}$ ini kemungkinan disebabkan oleh adanya perbedaan durasi edukasi yang diberikan pada penelitian tersebut, subyek hanya diberikan satu kali penyuluhan dengan media leaflet, sedangkan penelitian pada penelitian ini diberikan 5 kali edukasi yang dibagi dalam dua tahap (saat hamil dan saat nifas). Edukasi gizi telah terbukti secara efektif dapat memodifikasi perilaku positif terkait dengan kualitas pola makan dan kesehatan. Penelitian sebelumnya yang dilakukan oleh Liu et al., telah menunjukkan bahwa pemberian edukasi gizi saat hamil dan dilanjutkan saat masa nifas memberi pengaruh signifikan pada kualitas perilaku makan seperti konsumsi buah, sayur, kedelai dan produk kedelai begitupun dengan pengetahuan gizi dan kesehatan dibandingkan dengan kelompok kontrol (tidak diberikan edukasi). ${ }^{21}$

Tidak ditemukannya efek pemberian suplementasi vitamin A dosis tinggi terhadap frekuensi maupun durasi morbiditas telah dilaporkan dalam beberapa penelitian sebelumnya..$^{5,922-23.24}$ Dalam penelitian ini, pemberian 2 kapsul vitamin A dosis tinggi tampak lebih baik dalam mengurangi kejadian morbiditas pada ibu dan bayi dibandingkan dengan pemberian 1 kapsul vitamin A. Hasil ini berbeda dengan penelitian yang dilakukan oleh Fernandes et al., yang menemukan bahwa tidak ada perbedaan rata-rata kejadian sakit ISPA maupun diare anak dari ibu yang memperoleh 2 kapsul vitamin A dibandingkan dengan yang memperoleh 1 kapsul vitamin A. ${ }^{24}$ Kemungkinan perbedaan waktu pemberian kapsul vitamin A khususnya untuk kelompok yang diberikan 1 kapsul, dapat mempengaruhi hasil. Pada penelitian Fernandes et al., ibu nifas diberikan 1 kapsul vitamin A sesaat setelah melahirkan sedangkan pada penelitian ini setiap ibu nifas diberikan 1 kapsul vitamin A pada akhir masa nifas ibu (minggu ke 6). Pada dasarnya konsentrasi vitamin A dalam ASI masih cukup tinggi dalam 21 hari pertama setelah ibu melahirkan, yakni dalam ASI kolostrum selama 4-6 hari dan ASI peralihan dalam 7-21 hari. ${ }^{13}$ Berdasarkan hal tersebut, ibu nifas yang diberikan kapsul vitamin A pada minggu ke 6 setelah melahirkan kemungkinan sudah mengalami penurunan kadar vitamin A dalam ASI nya dan akhirnya akan berdampak pula pada semakin rendahnya kandungan vitamin A dalam tubuh bayi.

Salah satu efek langsung yang diharapkan berpengaruh dari pemberian suplementasi vitamin A dosis tinggi adalah adanya perubahan kadar vitamin A dalam ASI, dengan kandungan vitamin A yang cukup dalam ASI diharapkan dapat memberikan perlindungan terhadap bayi dari serangan penyakit infeksi. Hasil dari perubahan kadar vitamin A dalam ASI ibu nifas akibat pemberian intervensi tidak dibahas dalam artikel ini, akan tetapi akan dipaparkan pada artikel yang terpisah. Kebutuhan vitamin A bayi yang baru lahir sangat tergantung kualitas vitamin A dalam ASI serta proses pemberian ASI oleh ibu nifas. Pemberian ASI yang tidak ekslusif kepada bayi yang baru lahir akan berdampak pada semakin rendahnya 
kandungan vitamin A dalam tubuh bayi dan pada akhirnya akan berpengaruh terhadap daya tahan tubuh anak. Kekurangan vitamin A akan menyebabkan penurunan jumlah sel goblet dan sekresi mukus sehingga sel-sel epitel menjadi kering dan bersisik yang akhirnya menyebabkan mikroorganisme lebih mudah menyerang (infeksi). ${ }^{25}$

\section{KESIMPULAN DAN SARAN}

Hasil penelitian ini dapat disimpulkan bahwa pemberian minyak goreng yang telah difortifikasi dengan vitamin A lebih efektif dalam mencegah kejadian morbiditas (ISPA dan diare) baik pada ibu maupun anak dibandingkan dengan pemberian suplementasi vitamin A dosis tinggi serta edukasi gizi. Dalam hal ini juga bisa disarankan kepada pemerintah untuk sebaiknya sudah mulai mempertimbangkan alternatif untuk menanggulangi masalah kekurangan vitamin A baik pada ibu menyusui maupun bayi yang lahir selain dengan menggunakan suplementasi vitamin A dosis tinggi, yakni dengan menggalakkan konsumsi minyak yang sudah difortifikasi vitamin A disertai dengan pemberian edukasi terutama terkait gizi dan kesehatan saat hamil dan menyusui. Diharapkan ada penelitian lanjutan yang tidak hanya melihat efek suplementasi vitamin A terhadap morbiditas, melainkan juga terhadap mortalitas ibu maupun bayi.

\section{UCAPAN TERIMA KASIH}

Terima kasih diucapkan kepada; 1) Southeast Asian Minister of Education Organization Regional Center for Food and Nutrition (SEAMEO RECFON) - Pusat Kajian Gizi Regional Universitas Indonesia dan 2) Kementerian Riset Teknologi dan Pendidikan Tinggi yang telah membantu dalam pembiayaan penelitian ini.

\section{DAFTAR PUSTAKA}

1. Sommer A, Husaini G, Tarwotjo I, Susanto D. Increased Mortality in Children with Mild Vitamin A Deficiency. Lancet. 1983;2(8350):5858.

2. Imdad A, Ahmed Z, Bhutta Z. Vitamin Asupplementation for the Prevention of Morbidity and Mortality in Infants One to Six Months of Age (Review). Cochrane Database Syst Rev. 2016;9:CD007480.

3. Fujita M, Shell-Duncan B, Ndemwa P, Brindle
E, Lo Y, Kombe Y, et al. Vitamin A Dynamics in Breastmilk and Liver Stores: a Life History Perspective. Am J Hum Biol. 2011;23(5):66473.

4. Christian P, Jr KPW, Khatry SK, Katz J, Shrestha SR, Pradhan EK, et al. Night Blindness of Pregnancy in Rural Nepal-Nutritional and Health Risks. Int J Epidemiol. 1998;27(2):231-7.

5. Bahl R, Bhandari N, Wahed MA, Kumar GT, Bhan MK, Group the WI-LVA. Vitamin A Supplementation of Women Postpartum and of their Infants at Immunization Alters Breast Milk Retinol and Infant Vitamin A Status. J Nutr. 2002;132(11):3243-8.

6. Miller M, Humphrey J, Johnson E, Marinda E, Brookmeyer R, Katz J. Why do Children Become Vitamin A Deficient? J Nutr. 2002;132(9):2867S - 2880S.

7. Ahmed F, Azim A, Akhtaruzzaman M. Vitamin A Deficiency in Poor, Urban, Lactating Women in Bangladesh: Factors Influencing Vitamin A Status. Public Health Nutr. 2003;6(5):447-52.

8. Humphrey JH, Agoestina $\mathrm{T}, \mathrm{Wu} \mathrm{L}$, Usman A, Nurachim M, Subardja D, et al. Impact of Neonatal Vitamin A Supplementation on Infant Morbidity and Mortality. J Pediatr. 1996;128(4):489-96.

9. Roy S, Islam A, Molla A, Akramuzzaman S, Jahan F, Fuchs G. Impact of a Single Megadose of Vitamin A at Delivery on Breastmilk of Mothers and Morbidity of their Infants. Eur J Clin Nutr. 1997;51(5):302-7.

10. Klemm RDW, Labrique AB, Christian $P$, Rashid M, Shamim AA, Katz J, et al. Newborn Vitamin A Supplementation Reduced Infant Mortality in Rural Bangladesh. Pediatrics. 2008;122(1):e243-50.

11. Rotondi MA, Khobzi N. Vitamin A Supplementation and Neonatal Mortality in the Developing World: a Meta-Regression of Cluster-Randomized Trials. Bull world Heal Organ. 2010;88(9):697-702.

12. Bhaskaram $P$, Balakrishna N. Effect of Administration of 200,000 IU of Vitamin A to Women within 24 hrs after Delivery on Response to OPV Administered to the Newborn. Indian Pediatr. 1998;35(3):217-22. 
13. World Health Organization. Guideline: Vitamin A Supplementation in Postpartum Women. Geneva (CH): WHO; 2011.

14. Kementerian Kesehatan. Laporan Hasil Riset Kesehatan Dasar 2013. Jakarta (ID) : Kementerian Kesehatan RI; 2013.

15. Dary O, Mora JO. Food Fortification to Reduce Vitamin A Deficiency: International Vitamin A Consultative Group Recommendations. J Nutr. 2002;132(9 Suppl):2927S - 2933S.

16. Sandjaja, Jus'at I, Jahari AB, Ifrad, Htet MK, Tilden RL, et al. Vitamin A-Fortified Cooking Oil Reduces Vitamin A Deficiency in Infants, Young Children and Women: Results from a Programme Evaluation in Indonesia. Public Heal nutr. 2015;18(14):2511-22.

17. Newman V. Vitamin A and Breastfeeding: a Comparison of Data Form Developed and Developing Countries. San Diego (US). Wellstart International; 1993.

18. Muslimatun S, Schmidt MK, West CE, Schultink W, Hautvast JGA., Karyadi D. Weekly Vitamin A and Iron Supplementation During Pregnancy Increases Vitamin A Concentration of Breast Milk but Not Iron Status in Indonesian Lactating Women. J Nutr. 2001;131:2664-9.

19. Semba RD. Vitamin A, Infenction and Immune Function. In: Calder PC, Field CJ, Gill HS, editors. Nutrition and Immune Function. London (GB): CABI Publishing; 2002. p. 151.
20. Abdullah, Prawirohartono EP, Helmiyati S. Efek Suplementasi Vitamin A pada Ibu Nifas terhadap Pertumbuhan Bayi Umur 0-4 Bulan. J Gizi Klin Indones. 2013;9(3):97-103.

21. Liu N, Mao L, Sun X, Liu L, Yao P, Chen B. The Effecf of Health and Nutrition Education Intervention on Women's Postpartum Beliefs and Practices : a Randomized Controlled Trial. BMC Public Health. 2009;9(45):1-9.

22. Darboe MK, Thurnham DI, Morgan G, Adegbola RA, Secka O, Solon JA, et al. Effectiveness of an Early Supplementation Scheme of High-Dose Vitamin A Versus Standard WHO Protocol in Gambian Mothers and Infants: a Randomised Controlled Trial. Lancet. 2007;368(9579):2088-96.

23. Idindili B, Masanja H, Urassa H, Bunini W, Jaarsveld $\mathrm{P}$ van, Aponte JJ, et al. Randomized Controlled Safety and Efficacy Trial of 2 Vitamin A Supplementation Schedules in Tanzanian Infants. Am J Clin Nutr. 2007;85(5):13129.

24. Fernandes TF dos S, Figueiroa JN, Arruda IKG de, Diniz A da S. Effect on Infant Illness of Maternal Supplementation with 400000 IU vs 200000 IU of Vitamin A. Pediatrics. 2012;129(4):e960-6.

25. Villamor E, Fawzi WW. Effects of Vitamin A Supplementation on Immune Responses and Correlation with Clinical Outcomes. Clin Microbiol Rev. 2005;18(3):446-64. 